\title{
LEARNING STRATEGIES USED BY THE BRITISH INSTITUTE FOR UPPER INTERMEDIATE AND ADVANCED STUDENTS
}

\author{
Iin Rachmawati \\ University of 17 Agustus Surabaya \\ iinrachmawati85@gmail.com
}

\begin{abstract}
Practicing is an important factor in learning a second language. People all over the world learn their first language and also second language through practice with other people. Yet, different people may use different ways of learning, which are known as learning strategies. This study is concerned with language learning strategies reported to be used by students of upper intermediate and advanced level at a private language institute in Surabaya. It aims to identify the learning strategies most frequently used by the two groups of respondents and to identify differences and similarities in strategy used by the two groups. This research uses descriptive qualitative method. Using Rebecca Oxford's Strategy Inventory for Language Learning (SILL), the study found that the two groups of respondents used different types of learning strategies. Most frequently used strategies by the upper intermediate students include cognitive, compensation, and meta-cognitive strategies, while the advanced students mostly used social strategies. In addition, the two groups of students showed other differences and some similarities in the strategy use in terms of both type and frequency.
\end{abstract}

Keywords: learning strategies; upper intermediate level; advanced level; types of learning strategies

\section{INTRODUCTION}

Practicing is an important factor determining the success of language learning. People who have opportunity to practice a language will acquire the language fast. Nowadays, most people in Indonesia still have difficulties in learning English as a foreign language as they have lack opportunity to practice English. This condition is worsened by people attitudes toward English learners. Moreover besides practice, there are some other factors that affect second language learning, such as age, attitude, intelligence, personality, motivation, and attitude. Regarding age factor, Lightbown (1993) says that the earlier the learners know about second language, the greater the degree of success in learning a second language. Aptitude and intelligence factors affect second language learning on skill to accept the material. The last three factors: motivation, attitude, and personality come from the learners themselves. They determine learner's strategy in language learning.

Language learning strategies are very important to people who want to learn a second language and a foreign language. The success of English language learning in Indonesia also depends on the use of learning strategies in a classroom. Language learning strategies research began in the 1970s with the work of Joan Rubin, who, like Stern (1975), suggested 
that a model of "the good language learner" could be constructed by looking at special strategies used by successful second language students (Rubin, 1975).

In any educational courses and institutions, teachers still play the most crucial role. The teachers have to lead their students in order to make their students have a good strategy in learning second language. Hence, teachers should also have a good relationship with their students in order to make the teaching-learning activity become successful. Unfortunately, teachers sometimes are not aware of the idea of learners' strategy. This condition is worsened by a group of low motivated students and a bad selection of learning materials.

In many cases, students do not succeed in learning English since they have no learning strategy. Actually, learning strategy is one great way to learn English faster, easier, and more efficient. By using learning strategy, the students can get a simple way to learn English. The more information about the way to learn a second language, the faster they can receive the materials. When students are motivated to learn, their chances of success will be much higher.

This study will discuss more about the differences and the similarities in strategies used by students of different level of proficiency: upper intermediate and advanced class.

\section{REVIEW OF LITERATURE}

\subsection{Second Language Learning}

In learning language, there are second language and foreign language. According to Oxford (1990), the target language, language being learned, can be either a second language or a foreign language. A second language has a social and communicative function within the community where it is learned. For example, Belgium and Canada as multilingual countries, where its people need more than one language to communicate for social, economic, and professional reasons.

\subsection{Role of Language Learning Strategies in Second Language Learning}

Language learning strategies (LLS) can help students develop communicative competence in second language learning (SLL). In order to develop students' communicative competence, language learning strategies are important because research suggests that training students to use language learning strategies can help them to become better language learners. A study by O' Malley and Chamot (1990) also suggests that effective second language learners are aware of the language learning strategies they use. 


\subsection{Language Learning Strategies}

Learning strategies basically refer to the activities in which learning is achieved. Oxford proposed six types of learning strategies: direct and indirect strategies which will be subdivided into six categories.

\subsubsection{Direct Strategies}

These strategies are directly involved the target language.

\section{Memory Strategies}

The key functions of memory strategies are storage and retrieval of new information (Oxford, 1996:58). By using these strategies, students are able to store important things that they have heard and read in their memory.

\section{Cognitive Strategies}

These strategies are essential in learning a new language. Such strategies are varied lots, ranging from repeating to analyzing expressions and summarizing.

\section{Compensation Strategies}

These strategies enable students to use new language for comprehension or production despite limitations in knowledge.

\subsubsection{Indirect Strategies}

These strategies support and manage language learning without directly involving the target language. These strategies coordinate the learning process.

\section{Metacognitive Strategies}

These strategies are actions which go beyond cognitive devices and provide way for learners to coordinate their own learning process.

\section{Affective Strategies}

These strategies refer to emotions, attitudes, motivations, and values. Those who know how to control emotion and attitude of learning are considered to be good language learners.

\section{Social Strategies}

In these strategies, we learn about communication that occurs between and among people. Language is a form of social behavior, thus language involves other people. Students like any other human beings, live together with their friends and they need language in order.

\subsection{Factors Affecting Strategy Choice}

Oxford and Nyikos (1989) distinguish factors affecting choice of second language learning strategies into three: motivation, years of study, and sex. They stated that the more motivated the students use learning strategies, the more often they learn the language. Students, who 
have been longer in studying the language, they will use strategies more often than do less experienced students. Finally, the girls use more frequent strategy than the boys.

\section{RESEARCH METHODS}

In doing this study, the writer used quantitative descriptive method because the writer used the average score (mean) in statistical calculation in order to calculate the most frequently used strategy in both upper intermediate and advanced class. The major characteristic of this quantitative method is that it includes deductive process which means process from general to specific actions (Cresswell, 1994).

Procedures for making generalizations about the characteristics of the population were based on information obtained from sample taken from the population. The population of this study were the students of The British Institute (TBI) Surabaya. And the sample of this study was taken from the upper intermediate class (eight students) and the advanced class (six students). The writer chose the respondents from upper intermediate and advanced class because those classes are in the two highest levels in TBI and the students have already had the competence to learn formal and informal English. And these two classes were chosen because the level gap is not too distant so that the comparison will become more realistic.

The data were collected through questionnaires which contained 50 questions about types of learning strategies, which was taken from Oxford's Strategy Inventory for Language Learning (SILL). Then, some informal interviews were also being done in order to make sure that the answers of each student were their fixed answers. For data analysis, the writer did three steps: calculating the scores from the questionnaires, putting the calculated scores in tables, and identifying the differences and similarities between strategies used by upper intermediate and advanced class.

\section{RESULTS AND DISCUSSIONS}

This part describes the results of the research and discusses the main points in it.

\subsection{Data Presentation and Analysis of Upper Intermediate Class}

It can be seen from the table 1 that cognitive, compensation, and metacognitive strategies have the highest mean, which indicates that those strategies are mostly used by upper intermediate students. The lowest mean occurs to memory and affective strategies. Based on the table above, it can be concluded that the upper intermediate students do not always or generally use learning strategies. The highest score from the table is 3.4, and according to Oxford, that score belongs to medium strategy. Therefore, it can also be concluded that all 
strategies used by students of upper intermediate class are at the medium level. Table 2 shows the learning strategies applied by the students from upper intermediate group.

Table 1. Learning Strategies Applied by Students from Upper Intermediate Group

\begin{tabular}{ccccccc}
\hline Respondents & $\begin{array}{c}\text { Memory } \\
\text { Strategies }\end{array}$ & $\begin{array}{c}\text { Cognitive } \\
\text { strategies }\end{array}$ & $\begin{array}{c}\text { Compensation } \\
\text { strategies }\end{array}$ & $\begin{array}{c}\text { Metacognitive } \\
\text { strategies }\end{array}$ & $\begin{array}{c}\text { Affective } \\
\text { strategies }\end{array}$ & $\begin{array}{c}\text { Social } \\
\text { strategies }\end{array}$ \\
\hline I & 3.3 & 3.5 & 3.5 & 3.1 & 3 & 3.7 \\
\hline II & 2.8 & 3 & 2.5 & 2.3 & 1.8 & 2.7 \\
\hline III & 2.8 & 3.3 & 3 & 3.1 & 3 & 2.8 \\
\hline IV & 2.7 & 3.5 & 3.3 & 3.9 & 2.2 & 2.5 \\
\hline V & 2.3 & 3.5 & 4 & 3.8 & 4 & 4 \\
\hline VI & 3.9 & 3.9 & 4 & 4 & 2.8 & 4 \\
\hline VII & 2.6 & 3 & 3.3 & 3.7 & 3.3 & 3.2 \\
\hline E & 20.4 & 23.7 & 23.6 & 23.9 & 20.1 & 22.9 \\
\hline X & 2.9 & 3.4 & 3.4 & 3.4 & 2.9 & 3.3 \\
\hline
\end{tabular}

Notes: E refers to the total scores of each type of strategies

$\mathrm{X}$ refers to the mean of the scores of each type of strategies

Basically, the use of cognitive strategies by higher level students are encouraged by class activities. They often use repeating practice such as saying or doing something over and over again. The situation in the class also supports them to do repeating practice as the teacher always asks the students to say something until they get the right pronunciation and intonation. In case of compensation strategies, students sometimes switch to their mother tongue if they do not know how to say it in English or by selecting the topic and getting help. Finally, when they are about to use metacognitive strategies, they often tend to correct their grammatical errors.

\subsection{Data Presentation and Analysis of Advanced Class}

Table 2 shows the learning strategies applied by the students from advanced group.

Table 2 Learning Strategies Applied by Students from Advanced Group

\begin{tabular}{ccccccc}
\hline $\begin{array}{c}\text { Respondent } \\
\text { s }\end{array}$ & $\begin{array}{c}\text { Memory } \\
\text { strategies }\end{array}$ & $\begin{array}{c}\text { Cognitive } \\
\text { strategies }\end{array}$ & $\begin{array}{c}\text { Compensation } \\
\text { strategies }\end{array}$ & $\begin{array}{c}\text { Metacognitive } \\
\text { strategies }\end{array}$ & $\begin{array}{c}\text { Affective } \\
\text { strategies }\end{array}$ & $\begin{array}{c}\text { Social } \\
\text { strategi } \\
\text { es }\end{array}$ \\
\hline I & 3.1 & 3.4 & 3.8 & 2.9 & 3.5 & 4.7 \\
\hline II & 2.7 & 2.9 & 2.2 & 2.7 & 3.3 & 2.8 \\
\hline III & 2.6 & 3.7 & 4.5 & 3 & 3.3 & 4.3 \\
\hline IV & 2.7 & 4.6 & 3.8 & 4 & 2.8 & 4.8 \\
\hline V & 2.6 & 3.2 & 3 & 3 & 3 & 4.2 \\
\hline VI & 3 & 2.4 & 2.5 & 3 & 2 & 3.2 \\
\hline E & 16.5 & 20.1 & 19.8 & 18.5 & 17.9 & 23.9 \\
\hline X & 2.8 & 3.4 & 3.3 & 3.1 & 2.9 & 3.9 \\
\hline
\end{tabular}

Notes: E refers to the total scores of each type of strategies 
$\mathrm{X}$ refers to the mean of the scores of each type of strategies

It can be seen from the table 2 that social strategies have the highest mean, which indicates that these strategies are mostly used by advanced students. The lowest mean occurs to memory strategies. Based on the table above, the use of social strategies by advanced class students can be categorized as high (with the score from 3.5 to 5.0) and the rest of the strategies are at the medium level of use. Although memory strategies are at the medium level of use, the mean score for these strategies is the lowest.

Since social strategies are the most frequent strategy used by advanced students, it is said that there are three sets of social strategies: asking questions, cooperating with others, and empathizing with others. One of the most basic social interactions is asking questions which is commonly used by these advanced students to get closer with the right answer and increase their understanding. The strategies chosen by these advanced students seem to have correlation with their age and their years of study. Advanced students are aged from 20 to 30 years old and they tend to have more experience in learning a second language than those who are younger than them. In case of years of study, they know exactly that in learning a second language, they have to practice it more often to be successful language learners.

\subsection{The Differences and Similarities in the Learning Strategies used by Upper Intermediate and Advanced Class Students}

There are three similarities between upper intermediate and advanced class students. First, the students in both classes do not have low use of strategies. Second, the students in both classes mostly have medium use of strategies. Third, the students in both classes have the same score mean of cognitive strategies and affective strategies. These similarities may have relationship with motivation. The more motivated the students use learning strategies, the more often they learn the language.

And there are also three differences between these two classes. First, the most frequently used strategies in upper intermediate class are cognitive, compensation, and metacognitive strategies. And the most frequently used strategy in advanced class is social strategies. Second, in upper intermediate class, there is no highly strategy used. In contrast, in advanced class, there is highly used strategy with mean 3.9. And the last difference concerns the average score of each individual. The average score of each individual in upper intermediate class is lower than the average score of each individual in advanced class. These differences may have something to do with the students' age and years of study. 


\section{CONCLUSION}

Learning is a process of acquiring or getting knowledge and skill by study, experience, or instruction which causes permanent change in an individual knowledge or behavior. Actually in learning something, someone needs a special way and special tool called strategy. So, learning strategies are steps taken by students to enhance their own learning. According to Oxford, learning strategies are taken by students to make learning easier, faster, more enjoyable, more self-directed, more effective, and more transferable to new situations. Language learning concerns both spoken and written language and all the four language skills: writing, speaking, reading, and listening. Appropriate language learning strategies result in improved proficiency and greater self-confidence.

In some cases, students do not learn according to their teacher's instruction. This fault may lie in the students' motivation but it could also lie in their failure to use learning strategies while instruction is occurring. Because of those reasons, it is better if the teachers are sure first that the students know how to learn effectively by using learning strategies. The role of language learning strategies (LLS) in second language learning (SLL) is actually that LLS can help students develop communicative competence in SLL. So, it can be concluded that learning styles and strategies have a big role in learning a second language.

The most frequently used strategies by Upper Intermediate students are cognitive, compensation, and metacognitive strategies. Based on this result, the Upper Intermediate students are more concerned with learning material and all mental processes. And the most frequently used strategy by Advanced students is social strategies which means that the strategy can help them more understand the materials through enhancing the communication skill between and among people.

\section{REFERENCES}

Creswell, J.W. (1994). Qualitative and Quantitative Approaches. New York: Sage publications.

O’Malley, JM. , \& Chamot, A.U. (1990). Learning Strategies in Second Language Acquisition. Cambridge: Cambridge University Press.

Oxford, R.L. (1990a). Language Learning Strategies: What Every Teacher Should Know. New York: Newbury House/Harper and Row. (1990b). Styles, Strategies, and Aptitude: Connections for Language Learning. In T.S. Parry \& C.W. Stansfield (Eds.), Language Aptitude Reconsidered (pp. 67-125). Englewood Cliffs, NJ: Prentice Hall.

Oxford, R. and Nyikos, M. (1989). Variables Affecting Choice of Language Learning Strategies by University Students. The Modern Language Journal, 73(3), 291-300. 
Rubin, J. (1975). What the "Good Language Learner” Can Teach Us. TESOL Quarterly, 9, 41-51.

Stern, H. H. (1975). What Can We Learn from the Good Language Learner?. Canadian Modern Language Review, 31(4), 304-318.

Willing, P. (1988). Studies on Second Language Learning Style. New York: Cambridge University Press 